\title{
PORTABLE PENETROMETER FOR AGRICULTURAL SOIL: SENSITIVITY TEST TO IDENTIFY CRITICAL COMPACTION DEPTH ${ }^{(1)}$
}

\author{
João Carlos Medeiros ${ }^{(2)}$, Getulio Coutinho Figueiredo ${ }^{(3)} \&$ Álvaro Luiz Mafra ${ }^{(4)}$
}

\begin{abstract}
To express the negative effects of soil compaction, some researchers use critical values for soil mechanical strength that severely impair plant growth. The aim of this study was to identify this critical compaction depth, to test the functionality of a new, portable penetrometer developed from a spring dynamometer, and compare it to an electronic penetrometer traditionally used in compaction studies of agricultural soils. Three soils with distinct texture were conventionally tilled using a disk plow, and cultivated with different plant species. The critical soil resistance defined to establish critical compaction depth was equal to 1.5 MPa. The results of the new equipment were similar to the electronic penetrometer, indicating its viability as a tool for assessing the soil physical conditions for plant growth.
\end{abstract}

Index terms: spring dynamometer, penetration resistance.

\section{RESUMO: PENETRÔMETRO PORTÁTIL PARA SOLOS AGRÍCOLAS: TESTE DE SENSIBILIDADE PARA IDENTIFICAÇÃO DA CAMADA CRÍTICA DE COMPACTAÇÃO}

Ao considerar os efeitos negativos da compactação do solo, alguns pesquisadores utilizam valores críticos para a resistência mecânica do solo na qual o crescimento de plantas é severamente prejudicado. Assim, o objetivo deste trabalho foi avaliar a profundidade da camada crítica de compactação, visando testar a funcionalidade de um novo penetrômetro

\footnotetext{
(1) Received for publication in August 2009 and approved in September 2010.

${ }^{(2)}$ Doctoring in Soils and Plant Nutrition, Escola Superior de Agricultura "Luiz de Queiroz", Universidade de São Paulo. Av. Pádua Dias 11, CEP 13418-900 Piracicaba (SP), Brazil. Email: medeiros.jc@gmail.com

(3) Agronomist, Post Doctorate student of Graduate Program in Soils and Plant Nutrition of Escola Superior de Agricultura "Luiz de Queiroz". E-mail: figueiredo.gc@gmail.com

(4) Universidade do Estado de Santa Catarina - UDESC. Av. Luiz de Camões 2090, CEP 88520-000 Lages (SC), Brazil. Email: a2alm@cav.udesc.br
} 


\begin{abstract}
portátil, desenvolvido a partir de um dinamômetro de mola, e compará-lo a um penetrômetro eletrônico tradicionalmente utilizado em estudos de compactação de solos agrícolas. O estudo foi desenvolvido em três solos distintos quanto à textura, submetidos ao preparo convencional com arado e cultivados com diferentes espécies vegetais. A camada crítica de compactação foi considerada aquela na qual a resistência ao penetrômetro foi igual a 1,5 MPa. O novo equipamento forneceu resultados similares aos do penetrômetro eletrônico, indicando sua viabilidade como instrumento de avaliação da condição física do solo para o crescimento de plantas.
\end{abstract}

Termos de indexação: dinamômetro de mola, resistência à penetração.

\section{INTRODUCTION}

Soil penetration resistance $(\mathrm{PR})$ is one of the most commonly used indicators of soil physical quality in agronomic evaluations (Beutler et al., 2001; Pedrotti et al., 2001). This is one of the physical properties which influences root growth and crop yield directly (Letey, 1985). PR is also used as an indicator of the effect of soil management systems (Tormena \& Roloff, 1996; Dexter et al., 2007; Ralisch et al., 2008; Veiga et al., 2009). It is determined by the use of penetrometers, which measure the resistance of the soil to penetration related to a standardized cone (ASAE, 1999), located at the end of a metal rod, which is inserted into the soil.

Penetrometers can be divided into two groups, depending on the penetration method: (a) dynamic or impact, where the cone is inserted into the soil by impacts from a metal object with a known mass (Stolf, 1991) and (b) static, where the cone is pushed into the soil at a speed as constant as possible, by manual action or hydraulic or electro-hydraulic mechanisms (constant speed). For example, coupled to tractor hydraulic systems or to utility vehicles with motors adapted for field use ((Wilford et al., 1972; Bradford, 1986; Perumpral, 1987; Rooney \& Lowery, 2000). However, the drawback of these systems is the damaging effects of vehicle traffic on the experimental areas.

With the aim of reducing the equipment size and to facilitate PR determination in experimental areas throughout the agricultural crop cycle, Lowery (1986) developed a penetrometer mounted on a tripod and equipped with a load cell, which allows the soil strength measurement when the cone is inserted. Simultaneously, this equipment with a batteryoperated electric motor measures the PR depth at a constant displacement rate. Schuler \& Lowery (1987) later modified the equipment and coupled it to a trolley with a self-leveling support table of the rod with the cone. Larney et al. (1989) also enhanced the equipment with a computer device for data entry and storage. However, these modifications are costly, which has for one thing hindered the widespread use of the equipment for the evaluation of soil physical quality.
To measure the negative effect of soil compaction associated with a reduction in aeration, water and nutrient availability and increased mechanical resistance to root growth (Letey, 1985), various researchers have used the concept of the least limiting water range, in which the limitations to plant growth and development in terms of air, water availability and soil resistance to penetration are considerably reduced (Silva et al., 1994; Klein \& Libardi, 2000, Beutler et al., 2004). However, others defend a simpler concept by establishing critical values to physical properties, such a soil density and PR. In this way, when these properties exceed the critical values, plant growth is severely restricted (Taylor \& Gardner, 1963; Taylor et al., 1966; Thompson et al., 1987; Reinert et al., 2001). So, determining compacted soil layers with simpler and portable penetrometers would be an adequate and cheap alternative. Similarly, various equipments have been tested to evaluate soil load support capacity (Ajayi et al., 2009).

The objective of this study was to test the functioning of a portable penetrometer to determine the layer of the critical compaction depth, comparing it to the traditionally used electronic penetrometer, in three soils of different texture.

\section{MATERIAL AND METHODS}

The study was carried out in Piracicaba - SP, in conventionally tilled areas (one plowing and three disking). The soils were, according to the Soil Survey Staff (2010), a Typic Hapludox (loamy texture class); Rhodic Kandiudalfic Eutrudox (clayey); and Typic Hapludult (sandy over loamy). The Hapludox and Hapludult were visibly drier than the Eutrudox at tilling, allowing less disk penetration in these soils. After soil tillage, sunn hemp (Crotalaria juncea) was sown on the Hapludox, Brachiaria (Brachiaria decumbens) on the Hapludult and maize (Zea mays), on the Eutrudox. The following penetrometers were tested: (a) electronic (reference), Falker brand, cone standardized according to ASAE (S.313.3), base diameter $12.83 \mathrm{~mm}$ and an angle of $30^{\circ}$ and (b) the proposed new, portable penetrometer, Hatô brand, 
consisting of a spring dynamometer with two calibrated reading scales for pressure units (MPa) and for soil strength $\left(\mathrm{kgf} \mathrm{cm}^{-2}\right)$ (Figure 1). The Hatô penetrometer works by the body mass of the operator applying the necessary pressure on the cone to penetrate the soil. To obtain a pressure of approximately $2 \mathrm{MPa}$ (base diameter of the penetration cone $12 \mathrm{~mm}$, angle $30^{\circ}$ ) only $1 / 3$ of the body mass of a person of $70 \mathrm{kgf}$ is required, making it easy for the operator to keep his/her balance during use.

Due to deterioration of the spring, the dynamometer was calibrated by measuring the force applied to the proposed equipment by an electronic weight scale. It was verified whether the values indicated on the dynamometer scale of $0.5,1.0,1.5$ and $2.0 \mathrm{MPa}$ corresponded to $5.8,11.5,17.3$ and $23.0 \mathrm{~kg}( \pm 5 \%)$, respectively, on the scale.

Approximately 90 days after soil tillage, readings were made with the two penetrometers, at a distance of $0.08 \mathrm{~m}$ from each other for paired data, considering that the soil was near field capacity (four days of draining after $25 \mathrm{~mm}$ of rain). In each soil, 40 observations per penetrometer were made at $2 \times 2 \mathrm{~m}$ intervals. The soil depth at which penetration resistance reached $1.5 \mathrm{MPa}$ was also determined, corresponding to the critical compaction depth.

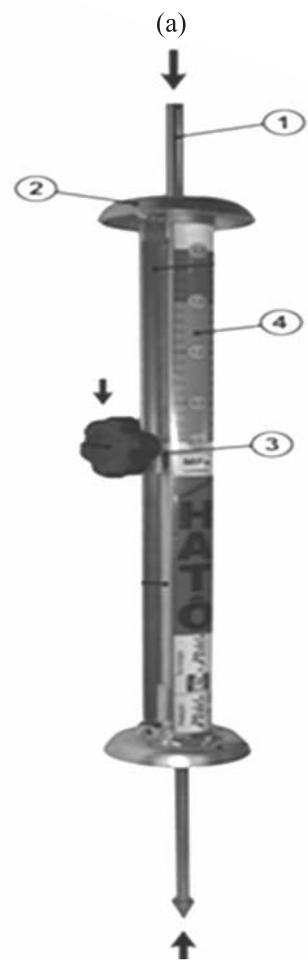

(b)

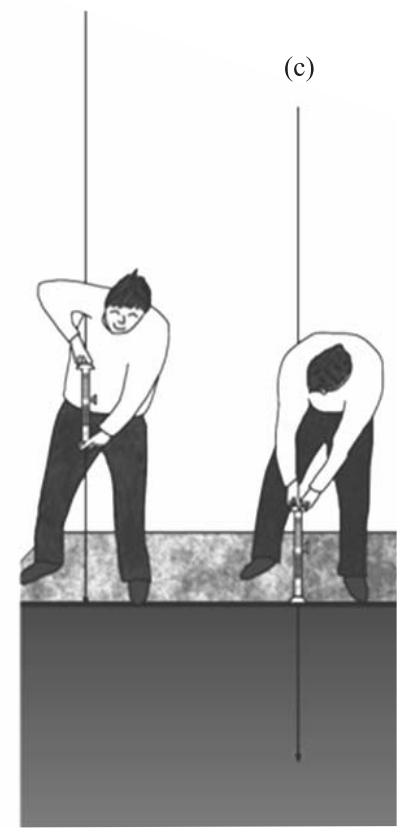

Figure 1. (a) Body of portable penetrometer, consisting of: rod with penetration cone (1), measuring body (2), spring dynamometer (3), measuring scale (4); (b): position at the beginning of the test and (c): position at the end of the test.
The normality of data distribution of the critical compaction depth was checked by the Shapiro-Wilk test, and the means t-tested for paired samples at $5 \%$ significance. To compare the performance of the penetrometers in determining critical compaction depth, graphs and linear regression adjustments were used as well as the following statistical indices; the index of agreement (Legates \& McCabe Jr., 1999); model efficiency (Legates \& McCabe Jr., 1999); mean absolute error (Legates et al., 1985); maximum error (Loague \& Green, 1991); root mean square error (RMSE) (Loague \& Green, 1991); random (rRMSE) and systematic (sRMSE) components of total normalized error (Legates \& McCabe Jr., 1999); and coefficient of residual mass (Loague \& Green, 1991) (Table 1).

The $\overline{\mathrm{O}}$ values correspond to the arithmetic mean, $\overline{\mathrm{O}}=\mathrm{N}^{-1} \sum_{\mathrm{i}=1}^{\mathrm{N}} \mathrm{O}_{\mathrm{i}}$ and $\hat{\mathrm{P}}_{\mathrm{i}}$ to the estimate of the variabledependent value (Legates et al., 1985), $\hat{\mathrm{P}}_{\mathrm{i}}=\mathrm{a}+\mathrm{bO}_{\mathrm{i}}$. In this study, $\mathrm{O}_{\mathrm{i}}$ corresponds to data measured by the Falker penetrometer and $\mathrm{P}_{\mathrm{i}}$ to data of the proposed equipment (Hatô). $\mathrm{N}$ is the number of experimental observations (Table 1).

\section{RESULTS AND DISCUSSION}

The equipments showed similarities in determining the compacted layer. It was observed that the critical compaction depth determined by the two penetrometers in the three soils studied did not differ (Figure 2). However, the critical compaction layer was deeper in the Eutrudox, which could be explained by the more efficient soil tillage applied under ideal soil moisture conditions (near field capacity). The Hapludult and Hapludox had been tilled at low soil moisture, preventing the disk plow from penetrating as deeply, resulting in less turning of the soil and, consequently, a compacted layer nearer the soil surface, sensitively detected by both penetrometers.

Despite the horizon with a naturally higher clay content in Hapludult soils (Embrapa, 2006), raising the density and resistance values measured by the penetrometer, no layer with pronounced texture gradient was observed in this Hapludult. Therefore, the depth of the compacted layer is more related to management practices, e.g., plowing, than to natural soil conditions.

Generally, linear regression analysis (Figure 3) showed a tendency for disparity between the means of depth of the compacted layer (when $\mathrm{PR}=1.5 \mathrm{MPa}$ ) of the penetrometers. The experimental points were generally aligned along the line 1:1, especially for the Hapludox and Hapludult. This confirms the similarity of measurements of the penetrometers tested 
Table 1. Additional statistical indices used to evaluate the performance of penetrometers

\begin{tabular}{|c|c|}
\hline Description & Equation \\
\hline Index of agreement (Legates \& McCabe Jr., 1999): & $\mathrm{d}=1-\frac{\sum_{\mathrm{i}=1}^{\mathrm{N}}\left(\mathrm{O}_{\mathrm{i}}-\mathrm{P}_{\mathrm{i}}\right)^{2}}{\sum_{\mathrm{i}=1}^{\mathrm{N}}\left(\mathrm{P}_{\mathrm{i}}-\overline{\mathrm{O}}|+| \mathrm{O}_{\mathrm{i}}-\overline{\mathrm{O}} \mid\right)^{2}}$ \\
\hline Deviation ratio (Loague \& Green, 1991): & $\mathrm{RD}=\frac{\sum_{\mathrm{i}=1}^{\mathrm{N}}\left(\mathrm{O}_{\mathrm{i}}-\overline{\mathrm{O}}\right)^{2}}{\sum_{\mathrm{i}=1}^{\mathrm{N}}\left(\mathrm{P}_{\mathrm{i}}-\overline{\mathrm{O}}\right)^{2}}$ \\
\hline Modeling efficiency (Legates \& McCabe Jr., 1999): & $\mathrm{EF}=1-\frac{\sum_{\mathrm{i}=1}^{\mathrm{N}}\left(\mathrm{O}_{\mathrm{i}}-\mathrm{P}_{\mathrm{i}}\right)^{2}}{\sum_{\mathrm{i}=1}^{\mathrm{N}}\left(\mathrm{O}_{\mathrm{i}}-\overline{\mathrm{O}}\right)^{2}}$ \\
\hline Mean absolute error (Legates et al., 1985): & $\mathrm{MAE}=\mathrm{N}^{-1} \sum_{\mathrm{i}=1}^{\mathrm{N}}\left|\mathrm{O}_{\mathrm{i}}-\mathrm{P}_{\mathrm{i}}\right|$ \\
\hline Maximum error (Loague \& Green, 1991): & $\mathrm{ME}=\max \left(\left|\mathrm{O}_{\mathrm{i}}-\mathrm{P}_{\mathrm{i}}\right|\right)_{\mathrm{i}=1}^{\mathrm{N}}$ \\
\hline Root mean square error (Loague \& Green, 1991): & $\mathrm{RMSE}=\left[\mathrm{N}^{-1} \sum_{\mathrm{i}=1}^{\mathrm{N}}\left(\mathrm{O}_{\mathrm{i}}-\mathrm{P}_{\mathrm{i}}\right)^{2}\right]^{0,5}\left(\frac{100}{\overline{\mathrm{O}}}\right)$ \\
\hline Random (rRMSE) and systematic (sRMSE) components of normalized & $\operatorname{rRMSE}=\left[\mathrm{N}^{-1} \sum_{\mathrm{i}=1}^{\mathrm{N}}\left(\hat{\mathrm{P}}_{\mathrm{i}}-\mathrm{P}_{\mathrm{i}}\right)^{2}\right]^{0,5}\left(\frac{100}{\overline{\mathrm{O}}}\right)$ \\
\hline total error (Legates \& McCabe Jr., 1999): & $\operatorname{sRMSE}=\left[\mathrm{N}^{-1} \sum_{\mathrm{i}=1}^{\mathrm{N}}\left(\hat{\mathrm{P}}_{\mathrm{i}}-\mathrm{O}_{\mathrm{i}}\right)^{2}\right]^{0,5}\left(\frac{100}{\overline{\mathrm{O}}}\right)$ \\
\hline Coefficient of residual mass (Loague \& Green, 1991): & $\mathrm{CMR}=\frac{\sum_{\mathrm{i}=1}^{\mathrm{N}} \mathrm{O}_{\mathrm{i}}-\sum_{\mathrm{i}=1}^{\mathrm{N}} \mathrm{P}_{\mathrm{i}}}{\sum_{\mathrm{i}=1}^{\mathrm{N}} \mathrm{O}_{\mathrm{i}}}$ \\
\hline
\end{tabular}

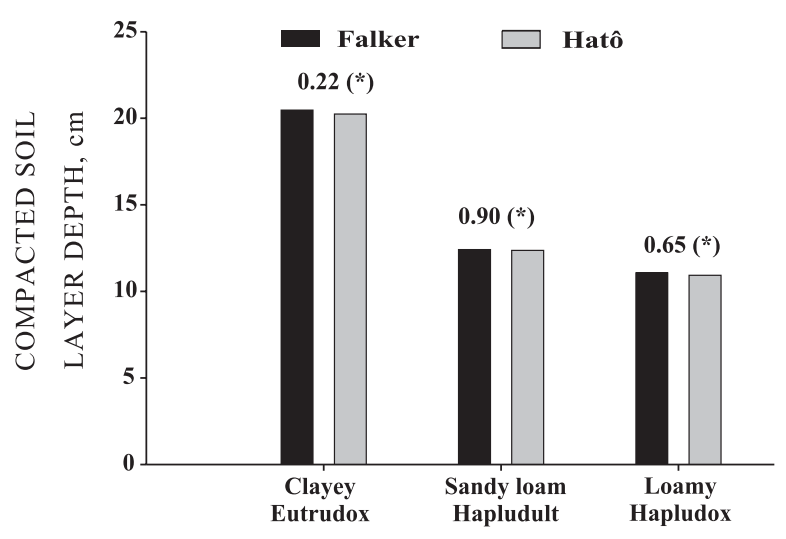

Figure 2. Soil compaction depth at which resistance is equal to 1.5 MPa, evaluated by two penetrometers in three soils in Piracicaba-SP; $(N=40)$ and (*) $=\{$ t test probability value, $\operatorname{Pr}>|\mathrm{t}|$ at $5 \%\}$

(Figure 2). Other statistics (Table 2) complete the evaluation of the consistency degree of the depth data of the compacted soil layer by the penetrometers "Falker" and "Hatô". If the consistency degree of the data generated by both penetrometers were perfect, these indices would result in: $\mathrm{R}^{2}=\mathrm{d}=\mathrm{RD}=\mathrm{EF}=1$ and $\mathrm{MAE}=\mathrm{ME}=\mathrm{CMR}=\mathrm{RMSE}=\mathrm{rRMSE}=\mathrm{sRMSE}=0$.

The values of the coefficient of determination $\left(\mathrm{R}^{2}\right)$ were considered satisfactory (>0.7) (Table 2). However, to analyze the relationship between experimental variables using only the coefficient of determination may not be sufficient for reliable conclusions about penetrometer performance. This is due, for example, to the insensitivity of $\mathrm{R}^{2}$ to the size of the difference between a reference value (control) and a value obtained by other methods (Willmott \& Wicks, 1980; Legates \& McCabe Jr., 1999). Therefore, a combined analysis with the other statistical indices is needed.

Although the $\mathrm{R}^{2}$ value was higher in the Hapludult only, the agreement index (d) values were very close to the unit (ideal condition) for the three soils studied. Furthermore, the behavior of the RD values of the penetrometers were similar regarding the mean data distribution of the compacted layer depth of the three soil types. This was confirmed by the EF values, which indicated consistency of the data means of the 


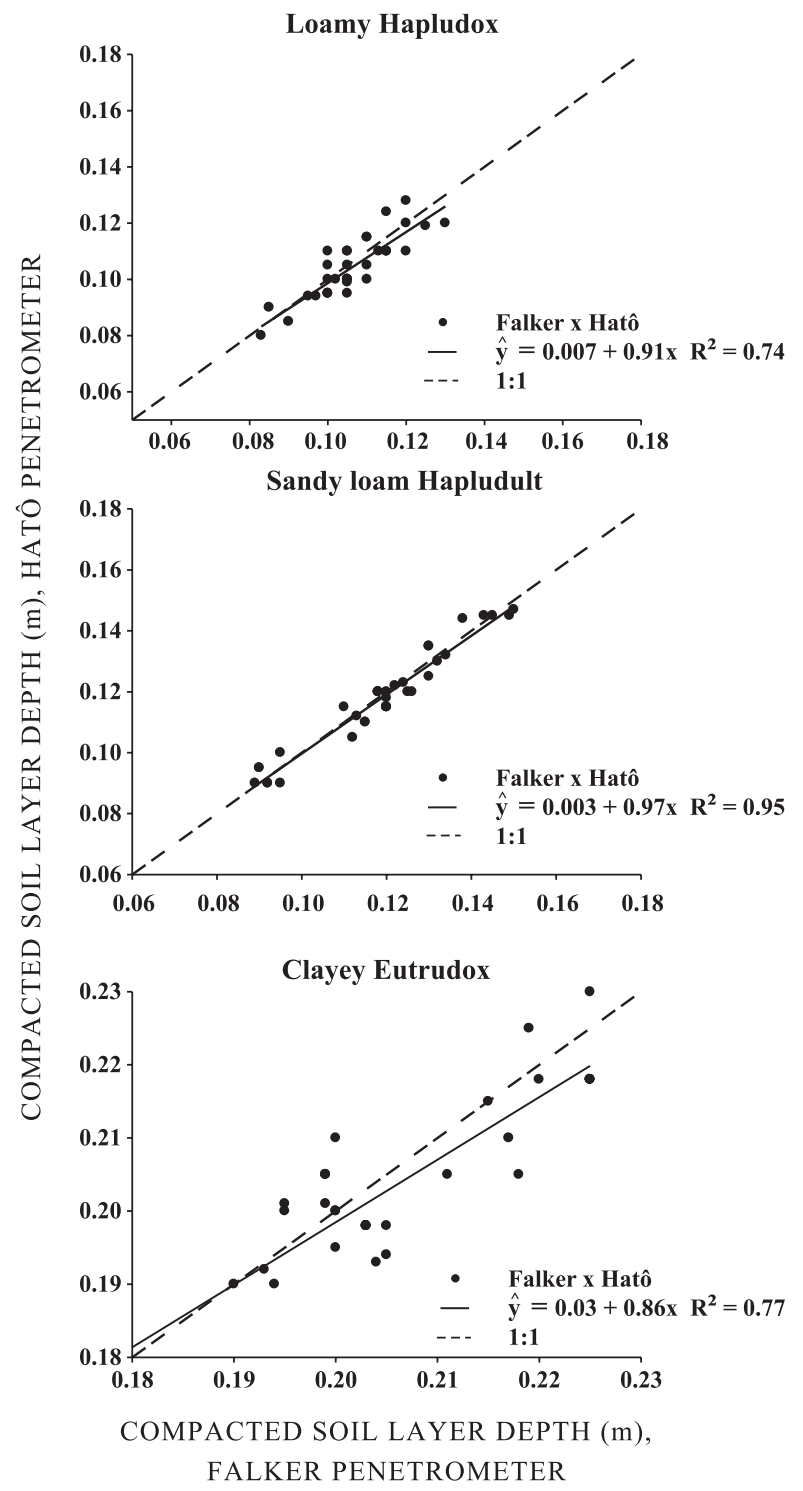

Figure 3. Comparison between soil depth values in which penetration is equal to $1.5 \mathrm{MPa}$, considering the proposed penetrometer (Hatô) and electronic penetrometer (Falker, as a reference) on three soils in São Paulo State. penetrometers. Moreover, the indices MAE and ME showed that the error magnitude of the data sets for the penetrometers was statistically acceptable.

Notably, RMSE, rRMSE and sRMSE, i.e. the percentage values of the total, random and systematic error, respectively, were very low compared to the mean depth of the compacted layer (Table 2). The magnitude of rRMSE was similar to that of RMSE, while sRMSE was always below these indices, confirmed by the CMR value (practically zero). These results show the predominance of random over systematic error in a comparison of the depth data of the compacted layer of the tested penetrometers, which is fundamental for the validation of the new apparatus. This shows that the magnitude of measurements with the "Hatô" and "Falker" penetrometers depended, principally, on the intrinsic properties of the soils evaluated.

Aside from management, factors such as soil texture and density can influence the PR depth values critical to plant growth and development (Hillel, 1971; Letey, 1985). The three soils studied belonged to different soil texture classes: clay in Eutrudox (320 $\mathrm{g} \mathrm{kg}^{-1}$ sand, $500 \mathrm{~g} \mathrm{~kg}^{-1}$ clay); sandy clay loam in the Hapludox (730 $\mathrm{g} \mathrm{kg}^{-1}$ sand, $230 \mathrm{~g} \mathrm{~kg}^{-1}$ clay), and sandy loam in the Hapludult $\left(780 \mathrm{~g} \mathrm{~kg}^{-1}\right.$ sand, $180 \mathrm{~g} \mathrm{~kg}^{-1}$ clay). These different values of soil particle size distribution generate distinct structures and alter the soil physical behavior under mechanical force of the soil management, affecting the penetrometer resistance (Figure 2) as well as soil water conditions.

Since PR is one of the soil physical properties directly related to plant growth and development (Letey, 1985), it is worth remembering the importance of the proposed equipment due to its low cost and easy transport and operation, which enables farmers to diagnose a series of problems caused by soil compaction more easily. Furthermore, the Hatô penetrometer allows measurements to a depth of $1.5 \mathrm{~m}$, offering a comprehensive and precise diagnostic of the soil compaction state, which is particulalry important in cases of a deep root system, for example, of sugar cane and in fruit orchards.

Table 2. Indices ${ }^{(1)}$ to verify the agreement between soil depth values where penetration resistance is equal to 1.5 MPa, based on the proposed penetrometer (Hatô) and the electronic penetrometer (Falker, as a reference) on three soils in São Paulo State

\begin{tabular}{lcccccccccc}
\hline \multicolumn{1}{c}{ Soil } & $\mathbf{R}^{2}$ & $\mathbf{d}$ & $\mathbf{R D}$ & $\mathbf{E F}$ & $\mathbf{M A E}$ & $\mathbf{M E}$ & $\mathbf{C M R}$ & $\mathbf{R M S E}$ & rRMSE & sRMSE \\
\hline & & & & & \multicolumn{2}{c}{$\mathrm{MPa}$} & & & & \\
Eutrudox & 0.770 & 0.924 & 1.005 & 0.716 & 0.005 & 0.013 & 0.012 & 2.82 & 2.49 & 1.53 \\
Hapludult & 0.946 & 0.985 & 1.009 & 0.943 & 0.003 & 0.007 & 0.008 & 3.15 & 3.04 & 0.93 \\
Hapludox & 0.741 & 0.918 & 0.872 & 0.669 & 0.005 & 0.010 & 0.018 & 5.14 & 4.85 & 2.59 \\
\hline
\end{tabular}

(1) $R^{2}$ : coefficient of determination; d: agreement index; RD: deviation rate; EF: modeling efficiency; MAE: mean absolute error; ME: maximum error; RMSE: root mean square error; rRMSE: random root mean square error; sRMSE: systematic root mean square error; CMR: coefficient of residual mass. MAE and ME are expressed in MPa unit while RMSE, rRMSE and sRMSE are expressed in percentage units. The other statistical indices are adimensional. 


\section{CONCLUSIONS}

1. The results of the proposed equipment (Hatô penetrometer) to determine the critical compaction depth were similar to the electronic penetrometer, already widely used in agronomic evaluations.

2 . The lower cost, easy use, reduced maintenance and ease of transport favor the use of the Hatô penetrometer by farmers and soil scientists.

\section{ACKNOWLEDGEMENTS}

We thank the Mississippi Agricultural and Forestry Experiment Station (Mafes) for developing and providing the equipment as well as for the support in conducting the experiment.

\section{LITERATURE CITED}

AJAYI, A.B.; DIAS JUNIOR, M.S.; CURI, N.; ARAUJO JUNIOR, C.F.; ALADENOLA, O.O.; SOUZA, T.T.T. \& INDA JUNIOR, A.V. Comparison of estimation methods of soil strength in five soils. R. Bras. Ci. Solo, 33:487-495, 2009 .

AMERICAN SOCIETY OF AGRICULTURAL ENGINEERS ASAE. Procedures for using and reporting data obtained with the soil cone penetrometer. St. Joseph, 1999. p.964966. (ASAE standard: ASAE EP542).

BEUTLER, A.N.; SILVA, N.L.N.; CURI, N.; FERREIRA, M.M.; CRUZ, J.N. \& PEREIRA FILHO, I.A. Resistência a penetração e permeabilidade de Latossolo Vermelho distrófico típico sob sistemas de manejo na região dos cerrados. R. Bras. Ci. Solo, 25:167-177, 2001.

BEUTLER, A.N.; CENTURION, J.F.; SILVA, A.P.; ROQUE, C.G. \& FERRAZ, M.V. Compactação do solo e intervalo hídrico ótimo na produtividade de arroz de sequeiro. Pesq. Agropec. Bras., 39:557-580, 2004.

BRADFORD, J.M. Penetrability. In: KLUTE, A., ed. Methods of soil analysis: Physical and mineralogical methods. 2.ed. Madison, American Society of Agronomy, 1986. p.463478.

DEXTER, A.R.; CZYZ, E.A. \& GATE, O.P. A method for prediction of soil penetration resistance. Soil Till. Res., 93:412-419, 2007.

EMPRESA BRASILEIRA DE PESQUISA AGROPECUÁRIA EMBRAPA. Centro Nacional de Pesquisa de Solos. Sistema brasileiro de classificação de solos. 2.ed. Rio de Janeiro, 2006. 306p.

HILLEL, D. Soil and water: Physical principles and processes. New York, Academic Press, 1971.

KLEIN, V.A \& LIBARDI, P.L. A faixa de umidade menos limitante ao crescimento vegetal e a sua relação com a densidade do solo ao longo de um perfil de um Latossolo Roxo. Ci. Rural, 30:959-64, 2000.
LARNEY, F.J.; HUFFMAN, R.L.; SCHULER, R.T.; TAYLOR, D.R.; KLADIVKO, E.J. \& LOWERY, B. A portable, selfleveling, constant-rate cone penetrometer with cone penetrometer with computer-controlled data acquisition for tillage studies. Soil Till. Res., 14:231-239, 1989.

LEGATES, D.R.; O'DONNELL, J. \& ROWE, C.M. Statistics for the evaluation and comparison of models. J. Geophys. Res., 90:8995-9005, 1985.

LEGATES, D.R. \& McCABE Jr., G.J. Evaluating the use of "goodness-of-fit" measures in hydrologic and hydroclimatic model validation. Water Sci. Res., 35:233-241, 1999.

LETEY, J. Relationship between soil physical properties and crop production. Adv. Soil Sci., 1:277-294, 1985.

LOAGUE, K. \& GREEN, R.G. Statistical and graphical methods for evaluating solute transport models: Overview and application. J. Contam. Hydrol., 7:51-73, 1991.

LOWERY, B. A portable constant-rate cone penetrometer. Soil Sci. Soc. Am. J., 50:412-414, 1986.

PEDROTTI, A.; PAULETTO, E.A; CRESTANA, S.; FERREIRA, M.M.; DIAS JUNIOR, M.S.; GOMES, A.S. \& TURATTI, A.L. Resistência mecânica à penetração de um Planossolo submetido a diferentes sistemas de cultivo. R. Bras. Ci. Solo, 25:521-529, 2001.

PERUMPRAL, J.V. Cone penetrometer applications - a review. Trans. Am. Soc. Agron. Eng., 30:939-44, 1987.

RALISCH, R.; MIRANDA, T.M.; OKUMURA, R.S.; BARBOSA, G.M.C.; GUIMARAES, M.F.; SCOPEL, E. \& BALBINO, L.C. Resistência à penetração de um Latossolo Vermelho Amarelo do Cerrado sob diferentes sistemas de manejo. R. Bras. Eng. Agr. Amb., 12:381-384, 2008.

REINERT, D.J.; REICHERT, J.M. \& SILVA, V.R. Propriedades físicas de solos em sistema plantio direto irrigado. In: CARLESSO, R.; PETRY, M. T.; ROSA, G. M. \& CERETTA, C. Irrigação por aspersão no Rio Grande do Sul. Santa Maria, Palloti, 2001. p.114-133.

ROONEY, D.J. \& LOWERY, B. A profile cone penetrometer for mapping soil horizons. Soil Sci. Soc. Am. J., 64:2136$2139,2000$.

SCHULER, R.T. \& LOWERY, B. A self-leveling portable constant rate penetrometer. St. Joseph, ASAE, 1987. 8p. (Paper 87-1520).

SILVA, A.P.; KAY, B.D. \& PERFECT, E. Characterization of the least limiting water range of soils. Soil Sci. Soc. Am. J., 58:1775-81, 1994.

SOIL SURVEY STAFF. Keys to soil taxonomy. 11.ed. Washington, USDA-Natural Resources Conservation Service, 2010. 338p.

STOLF, R. Teoria e teste experimental de fórmulas de transformação dos dados de penetrômetro de impacto em resistência do solo. R. Bras. Ci. Solo, 15:229-235, 1991.

TAYLOR, H.M. \& GARDNER, H.R. Penetration of cotton seedling taproots as influenced by bulk density, moisture content and strength of soil. Soil Sci., 96:153-6, 1963. 
TAYLOR, H.M.; ROBERSON, G.M. \& PARKER, J.J. Soil strength-root penetration relations for medium- to coarsetextured soil materials. Soil Sci., 102:18-22, 1966.

THOMPSON, P.J.; JANSEN, I.J. \& KOOKS, C.L. Penetrometer resistance and bulk density as parameters for predicting root system performance in mine soils. Soil Sci. Soc. Am. J., 51:1288-1293, 1987.

TORMENA, C.A. \& ROLOFF, G. Dinâmica da resistência à penetração de um solo sob plantio direto. R. Bras. Ci. Solo, 20:333-339, 1996.
VEIGA, M.; HORN, R.; REINERT D.J. \& REICHERT, M.J. Soil compressibility and penetrability of an Oxisol from Southern Brazil, as affected by long-term tillage systems. Soil Till. Res., 92:104-113, 2007.

WILFORD, J.R.; WOOTEN, O.B. \& EUGHAM, F.E. Tractor mounted field penetrometer. Trans. Am. Soc. Agron. Eng., 15:226-227, 1972.

WILLMOTT, C.J. \& WICKS, D.E. An empirical method for the spatial interpolation of monthly precipitation within California. Phys. Geog., 1:59-73, 1980. 